Svitlana V. Tsymbal

PhD of Psychology,

Associate Professor of the Department of English for Technical and Agrobiological Specialities

National University of Life and Environmental Sciences of Ukraine, Kyiv, Ukraine

svittsy@gmail.com

\title{
ENHANCING STUDENTS' CONFIDENCE AND MOTIVATION IN LEARNING ENGLISH WITH THE USE OF ONLINE GAME TRAINING SESSIONS
}

\begin{abstract}
Effective ESL teaching/learning has always been one of the most important interest areas for researchers and educators-practitioners. Over the past twenty years, teaching methods have been developed to enhance the students' motivation and self-confidence with the purpose of improving their language skills. Learners with higher motivation do better in English, and learners with self-confidence tend to be more successful in learning. The contemporary society is constantly changing and developing new technologies. Using online games in ESL classroom is one of such methods supplementing the teaching-learning process. Learners are often motivated by hands-on and active learning opportunities. The students are able to work on accomplishing a goal by choosing specific actions. They experience the consequences of the actions, which is one of the ways that a game-based learning experience is similar to real life. In this article, we examined how the Kahoot game-based method of teaching ESL may affect the attitude of university students towards the language and their level of motivation and confidence. The obtained data revealed that using Kahoot training sessions was mostly successful in enhancing students' confidence and motivation in learning English and the majority of students revealed positive attitudes to using Kahoot in language learning. However, $11 \%$ of students considered using online games to be a waste of time and $22 \%$ of students thought that learning English should not have fun as a necessary requirement. The author suggests that game-based method of teaching could be of use when utilized systematically over the academic year. However, university teachers should try various approaches and strategies to create a supportive learning environment in the classroom where learners feel interested, safe and secure to set and pursue their learning goals.
\end{abstract}

Keywords: confidence; motivation; ESL teaching/learning; Kahoot; training sessions; university students.

\section{INTRODUCTION}

The problem setting. Learning English as a Second Language (ESL) can be extremely exciting and challenging at the same time. It has been proved that learners with higher motivation do better in English, and learners with self-confidence tend to be more successful in learning. Motivation and self-confidence in learning English have always been the centre of attention among teachers and researchers. The contemporary society is constantly changing and developing new technologies. Using online games in ESL classroom is one of such methods supplementing the teaching-learning process. Games are fun activities that promote learning motivation, critical thinking, interaction, and problem solving. According to B. Martinson and S. Chu, "games are effective tools for learning because they offer students a hypothetical environment in which they can explore alternative decisions without the risk of failure. Thought and action are combined into purposeful behaviour to accomplish a goal. Playing games teaches us how to strategize, to consider alternatives, and to think flexibly" [2, 478]. Games stimulate interactivity and allow the students to work collaboratively as a team towards a common goal. This collaborative effort promotes motivation to succeed and learn from each other. Thus, the development of new technologies has shifted the learning process from conventional teaching into contemporary learning. Kahoot is a tool for using technology to administer quizzes, discussions or surveys. It is a game based classroom response system played by the whole class in real time. Kahoot as a game-based approach to language learning 
has been proved to be workable worldwide because Kahoot games and quizzes can easily attract students' attention, thus influencing their motivation and enhancing foreign language ability [4; 9]. Despite this interest in using online game-based learning, there is lack of empirical evidence supporting the validity of this approach in the Ukrainian context, which makes our study topical.

Analysis of recent studies and publications. So far, there have been conducted a great number of domestic and foreign studies related to using online games in ESL learning/teaching $[1 ; 2 ; 3 ; 6 ; 7 ; 12 ; 13]$. For one, Yu. Demianova's research shows that collaborative games bring positive results, such as deeper understanding of content, improved self-esteem, and higher motivation to remain on a language task. The research argues that "by playing collaborative games, students will become critical thinkers, learn to work with one another, and apply these skills to deal with stressful situations, and understand the importance of working together as a team to be successful" [13]. N. Iaremenko examines the potentials of online games in order to motivate ESL students, and summarizes the positive effects of playing learning games. In her research article, the author proves that online learning games can foster intrinsic motivation and help engage students in learning activities [9]. A. Yudintseva claims that "game-enhanced learning provides a set of effective strategies, such as language repetitions and contextual clues, to practice and use vocabulary in the authentic context" [3]. Online games are not activities mainly aimed to break the ice between students or divert from routine activities, but a way of getting the learner to use the language in the natural context. Games provide a constructivist classroom environment where students learn through performance, active discovery, from their own mistakes and also from each other, which involves extensive cognitive processing [1]. The students also "use their new knowledge in a situation separate from the activity in which they learned it" $[1,5]$. The findings of H. Chen's and T. Yang's study suggest that adventure video games can provide useful input to help students enhance their English listening, reading, vocabulary skills and learning motivation [7]. Thus, online games have a potential to boost language learning and make this process more engaging and effective.

The purpose of this study is to discover whether using Kahoot training sessions will:

- stimulate students' interest towards learning English, and

- enhance their learning motivation and confidence through developing stronger communication skills.

\section{RESEARCH METHODS}

In our study we used both theoretical (literature review) and empirical methods (questionnaires) to make it possible to answer the main questions addressed in the present paper. The study involved 72 freshmen (3 groups of students) who had a similar English learning experience. They were 29 female $(N=19)$ and 43 male $(N=11)$ freshmen. The study was conducted during semester I of the 2017-2018 academic year at the National University of Life and Environmental Sciences of Ukraine. The design of this study was quantitative in nature, as well as descriptive and inferential. Two questionnaires were employed as a measuring instrument. The participants were required to answer all the items of the questionnaires, giving their own opinion about 1) their experience of learning English and 2) their attitudes toward using Kahoot games in learning English to boost their learning motivation and confidence. 


\section{THE RESULTS AND DISCUSSION}

According to the goals of this study, the researcher aims to investigate how Kahoot games affect students' motivation and confidence to build their stronger communication skills - the two powerful factors in ESL learning.

Motivation is known as a stimulant for achieving a specific target [11]. According to R. Gardner's theory [10], motivation is a kind of central mental engine or energy-center that includes effort, want or will (cognition) and task-enjoyment (affect). Motivation provides the primary momentum to initiate L2 learning and all the other factors involved in L2 acquisition presuppose motivation to some extent. Without sufficient motivation, even individuals with the most remarkable abilities cannot accomplish long-term goals, and neither are appropriate curricula and good teaching enough on their own to ensure learner achievement.

According to N. Iaremenko, "motivating students and encouraging engagement is a challenge for teachers" [9, 127]. Learning motivation is considered to be "a key factor to success in second language acquisition which can develop students' curiosity about learning English" [14]. The author of this paper suggests that the use of Kahoot-based training sessions in ESL learning will show the direct relationship between engaging gamified learning and increased motivation.

Another aspect of effective ESL learning is learner confidence. Researchers have reported a positive relationship between self-confidence and learning of foreign languages [8; 15]. In the context of learner-centred learning and curricular reform, self-confidence is invoked as an important construct. Self-confidence usually comes from previous positive or negative language experience. Low self-confidence can have a negative effect on learning new languages and can lead to such psychological conditions as insecurity, fear, anxiety and antisocial behaviour [5]. Strong self-confidence makes the learner want to improve in the language, and this leads to positive results. Being a confident language learner means "being able to use English in different social and transactional contexts and with people from different cultural and professional backgrounds" [8]. Confident language learners are more likely to engage in conversations in English, are happier and more effective learners, whatever their level. According to F. Rubio, there is a correlation between language learner confidence and learning environment. Therefore, teachers' behaviour, activities students are required to take part in are directly correlated with building learner confidence. According to S. Tsymbal, "teachers should do their best to reduce anxiety in their students by creating an attractive, warm atmosphere inside the classrooms and increasing students' motivation in learning English" [15]. They should build students' self-confidence by using positive reinforcement, encouragements and by utilizing special trainings, activities and sessions, cooperative learning activities, for one, cooperative online games. In our paper, the author attempts to find out how using training sessions with the help of Kahoot games and quizzes influences learner confidence.

Prior to using Kahoot training sessions, students were given a questionnaire containing 18 questions about their feeling toward the conventional English lessons they used to have at school before entering the university, the teaching method used by teachers, their level of learning motivation and confidence and level of communication skills.

The responses to the questionnaire showed that the students generally were neutral in looking forward to English lessons (40\%). The participants' responses revealed that $32 \%$ of students did not feel confident to speak English and 38\% of students get confused to ask questions during the lesson. $41 \%$ (agree) and 18\% (strongly agree) of students thought that it is important to learn English and no one said that English is unimportant.

The questions focusing on the teaching methods revealed that $19 \%$ (strongly agree) and $38 \%$ (agree) liked it when the teacher uses visual aids, games, a lot of activities to teach 
English, however, only $27 \%$ of students $(10 \%+17 \%)$ preferred cooperative learning rather than independent activities and $28 \%$ of students $(12 \%+16 \%)$ liked working in groups when learning English.

Table 1

Students' feelings toward learning English before using Kahoot training sessions

\begin{tabular}{|c|c|c|c|c|c|}
\hline Statement & $\begin{array}{l}\text { Strongly } \\
\text { agree }\end{array}$ & Agree & Neutral & Disagree & $\begin{array}{l}\text { Strongly } \\
\text { disagree }\end{array}$ \\
\hline $\begin{array}{l}\text { 1. I usually look forward to my } \\
\text { English lesson }\end{array}$ & $9 \%$ & $22 \%$ & $40 \%$ & $25 \%$ & $4 \%$ \\
\hline $\begin{array}{l}\text { 2. I think it is important to learn } \\
\text { English }\end{array}$ & $18 \%$ & $41 \%$ & $39 \%$ & $2 \%$ & $0 \%$ \\
\hline $\begin{array}{l}\text { 3. I like doing grammar exercises in } \\
\text { the textbook in order to better learn } \\
\text { English }\end{array}$ & $5 \%$ & $6 \%$ & $8 \%$ & $39 \%$ & $42 \%$ \\
\hline $\begin{array}{l}\text { 4. I like working in groups when } \\
\text { learning English }\end{array}$ & $12 \%$ & $16 \%$ & $33 \%$ & $29 \%$ & $10 \%$ \\
\hline $\begin{array}{l}\text { 5.I think that learning English is } \\
\text { quite boring }\end{array}$ & $4 \%$ & $9 \%$ & $26 \%$ & $43 \%$ & $18 \%$ \\
\hline 6. I think English is hard to learn & $9 \%$ & $20 \%$ & $41 \%$ & $18 \%$ & $12 \%$ \\
\hline $\begin{array}{l}\text { 7. English is my favourite subject to } \\
\text { learn }\end{array}$ & $13 \%$ & $27 \%$ & $29 \%$ & $13 \%$ & $8 \%$ \\
\hline $\begin{array}{l}\text { 8. I like it when the teacher uses } \\
\text { visual aids, games, a lot of activities } \\
\text { to teach English }\end{array}$ & $19 \%$ & $38 \%$ & $24 \%$ & $18 \%$ & $1 \%$ \\
\hline $\begin{array}{l}\text { 9. I get confused to ask questions } \\
\text { during the lesson }\end{array}$ & $17 \%$ & $35 \%$ & $28 \%$ & $12 \%$ & $8 \%$ \\
\hline $\begin{array}{l}\text { 10. I prefer independent activities } \\
\text { rather than cooperative learning }\end{array}$ & $7 \%$ & $24 \%$ & $32 \%$ & $17 \%$ & $10 \%$ \\
\hline $\begin{array}{l}\text { 11. I do not feel confident to speak } \\
\text { English and it makes me feel } \\
\text { worried. }\end{array}$ & $27 \%$ & $32 \%$ & $26 \%$ & $8 \%$ & $7 \%$ \\
\hline $\begin{array}{l}\text { 12. When I miss a lesson, I never } \\
\text { ask my peers for the home task. }\end{array}$ & $4 \%$ & $6 \%$ & $46 \%$ & $23 \%$ & $21 \%$ \\
\hline $\begin{array}{l}\text { 13. I cannot apply the knowledge of } \\
\text { English in the real life }\end{array}$ & $19 \%$ & $34 \%$ & $25 \%$ & $18 \%$ & $4 \%$ \\
\hline $\begin{array}{l}\text { 14. I am not satisfied with my } \\
\text { achievements in English }\end{array}$ & $23 \%$ & $30 \%$ & $36 \%$ & $9 \%$ & $2 \%$ \\
\hline $\begin{array}{l}\text { 15. I have little motivation and } \\
\text { interest in learning English }\end{array}$ & $2 \%$ & $5 \%$ & $31 \%$ & $39 \%$ & $13 \%$ \\
\hline $\begin{array}{l}\text { 16. Learning English helps me to } \\
\text { communicate with native speakers } \\
\text { and surf the Internet }\end{array}$ & $14 \%$ & $23 \%$ & $31 \%$ & $21 \%$ & $11 \%$ \\
\hline $\begin{array}{l}\text { 17. Learning English with the help } \\
\text { of ICT is much more effective than } \\
\text { traditional learning }\end{array}$ & $22 \%$ & $29 \%$ & $36 \%$ & $12 \%$ & $1 \%$ \\
\hline $\begin{array}{l}\text { 18. I learn English just to pass the } \\
\text { exams }\end{array}$ & $4 \%$ & $11 \%$ & $28 \%$ & $30 \%$ & $27 \%$ \\
\hline
\end{tabular}

Despite the importance of learning English, 4\% strongly agreed that they learn English just to pass the exams and 2\% had little motivation and interest in learning English. 19\% of students strongly agreed that they could not apply the knowledge of English in the real life and for $14 \%$ and $23 \%$ of respondents learning English was not helpful in establishing contacts with native speakers or surfing the Internet. 
In order to change the students' attitudes towards learning English and boost their motivation and confidence we decided to conduct a series of training sessions for the students with the help of Kahoot game-based method of teaching ESL.

According to Talak-Kiryk, some characteristics of good games are as follows:

1. They are based on a learning objective.

2. They give the player control over their own destiny.

3. They include doable challenges.

4. They are fun and interesting, thus motivating.

5. They are based on reality in order to intrinsically motivate the players to continue to play the game.

6. They require interaction.

7. Games include every student [1, p.12-13].

Based on these statements, we developed a series of Kahoot-based training sessions ( 8 in total) to boost students' motivation and confidence in ESL (Table 2).

At the first stage we designed 8 Kahoot-based games according to the syllabus for the students of the Automatization and Computer Integrated Technology Faculty. At stage 2 students were explained the procedure of the game and the scoring rules. Stage 3 was the use of Kahoot-based games itself after which feedback was given to students.

Table 2

Stages of Kahoot-based Training Sessions

\begin{tabular}{|c|c|c|}
\hline Stage & Name & Content \\
\hline Stage 1: & Material Preparation & $\begin{array}{l}\text { The total number of } 8 \text { Kahoot-based games and quizzes } \\
\text { were designed on the topics (according to the syllabus for } \\
\text { the students of the Automatization and Computer Integrated } \\
\text { Technology Faculty): } \\
\text { - Types of energy. } \\
\text { - The history of electricity. } \\
\text { - Electricity and magnetism. } \\
\text { - The nature of magnetism. } \\
\text { - Electric current. } \\
\text { - Alternating current. } \\
\text { - Direct current. } \\
\text { - New elements of the Periodic Table. }\end{array}$ \\
\hline Stage 2: & Class Preparation & $\begin{array}{l}\text { Students were asked to bring their smart phones or laptops } \\
\text { to the classroom and explained the procedure of the game } \\
\text { and the scoring rules. }\end{array}$ \\
\hline Stage 3: & Kahoot training sessions & $\begin{array}{l}\text { The Kahoot games and quizzes designed by the researcher } \\
\text { were used to review the material learned during the practical } \\
\text { lessons. Giving feedback to students. }\end{array}$ \\
\hline
\end{tabular}

At the end of the semester, students were given another questionnaire consisting of 12 optional questions and 2 items of descriptive questions, in order to find out the students' attitudes toward using Kahoot in ESL learning and changes it made to their level of motivation and confidence. The results of the questionnaire are presented in Table 3. 
Table 3

Students' Attitudes toward Learning English after Using Kahoot Training Sessions

\begin{tabular}{|c|c|c|c|c|c|}
\hline Statement & $\begin{array}{l}\text { Strongly } \\
\text { agree }\end{array}$ & Agree & Neutral & Disagree & $\begin{array}{l}\text { Strongly } \\
\text { disagree }\end{array}$ \\
\hline $\begin{array}{l}\text { 1. I think using online learning } \\
\text { games is useful for both students } \\
\text { and teachers }\end{array}$ & $22 \%$ & $25 \%$ & $40 \%$ & $9 \%$ & $4 \%$ \\
\hline $\begin{array}{l}\text { 2. I think learning English should } \\
\text { not have fun as a necessary } \\
\text { requirement. }\end{array}$ & $8 \%$ & $14 \%$ & $39 \%$ & $23 \%$ & $16 \%$ \\
\hline $\begin{array}{l}\text { 3. I consider using online games is } \\
\text { a waste of time. }\end{array}$ & $5 \%$ & $6 \%$ & $8 \%$ & $39 \%$ & $42 \%$ \\
\hline $\begin{array}{l}\text { 4. I believe that game based } \\
\text { learning in higher education should } \\
\text { be an important teaching tool }\end{array}$ & $22 \%$ & $26 \%$ & $23 \%$ & $19 \%$ & $10 \%$ \\
\hline $\begin{array}{l}\text { 5. I believe that using online games } \\
\text { creates a more motivating learning } \\
\text { environment }\end{array}$ & $24 \%$ & $34 \%$ & $36 \%$ & $6 \%$ & $0 \%$ \\
\hline $\begin{array}{l}\text { 6. I felt more relaxed and confident } \\
\text { to use English during the training } \\
\text { session }\end{array}$ & $29 \%$ & $33 \%$ & $24 \%$ & $8 \%$ & $6 \%$ \\
\hline $\begin{array}{l}\text { 7. Working as a team helped me to } \\
\text { improve my English }\end{array}$ & $13 \%$ & $27 \%$ & $29 \%$ & $13 \%$ & $8 \%$ \\
\hline $\begin{array}{l}\text { 8. I found it to be fun and engaging } \\
\text { to learn English using online } \\
\text { games }\end{array}$ & $19 \%$ & $38 \%$ & $24 \%$ & $18 \%$ & $1 \%$ \\
\hline $\begin{array}{l}\text { 9. Comments from my teacher and } \\
\text { peers gave me more confidence to } \\
\text { try harder }\end{array}$ & $17 \%$ & $35 \%$ & $32 \%$ & $9 \%$ & $7 \%$ \\
\hline $\begin{array}{l}\text { 10. I feel I learned more vocabulary } \\
\text { and improved my memory during } \\
\text { the training sessions }\end{array}$ & $17 \%$ & $24 \%$ & $32 \%$ & $10 \%$ & $7 \%$ \\
\hline $\begin{array}{l}\text { 11. I was more active and engaged } \\
\text { in the activity during the training } \\
\text { sessions }\end{array}$ & $27 \%$ & $32 \%$ & $26 \%$ & $8 \%$ & $7 \%$ \\
\hline $\begin{array}{l}\text { 12. I feel I started speaking more } \\
\text { English at the training sessions }\end{array}$ & $21 \%$ & $23 \%$ & $46 \%$ & $6 \%$ & $4 \%$ \\
\hline
\end{tabular}

The data from Table 3 revealed that using Kahoot training sessions was successful in enhancing students' confidence and motivation in learning English. 22\% of students strongly agreed and $25 \%$ of students agreed that using online learning games is useful for both students and teachers; $24 \%$ and $35 \%$ of students respectively thought that using online games creates a more motivating learning environment. However, $11 \%(5 \%+6 \%)$ considered using online games to be a waste of time. $8 \%$ and $14 \%$ of students, respectively, thought that learning English should not have fun as a necessary requirement. Judging from the chart below, the percentage of students who felt positive effect of using Kahoot training sessions on their ESL learning was quite high.

In answer to the descriptive questions about what students liked best about using Kahoot in teaching/learning English, most of the students wrote they liked the engaging and cooperative atmosphere and wanted such games to be used often during English lessons. They also wrote that it gave them challenge to compete with other students and made them relaxed. Also, students mentioned that their level of motivation and confidence increased and they felt much more secure and safe. The total percentage of students who revealed increased motivation and confidence after Kahoot-based training sessions was 66\%; 28\% of students 
remained neutral and $6 \%$ of students wrote in the descriptive questions that their level of confidence and interest in English learning remained low during the training sessions (see Chart 1).

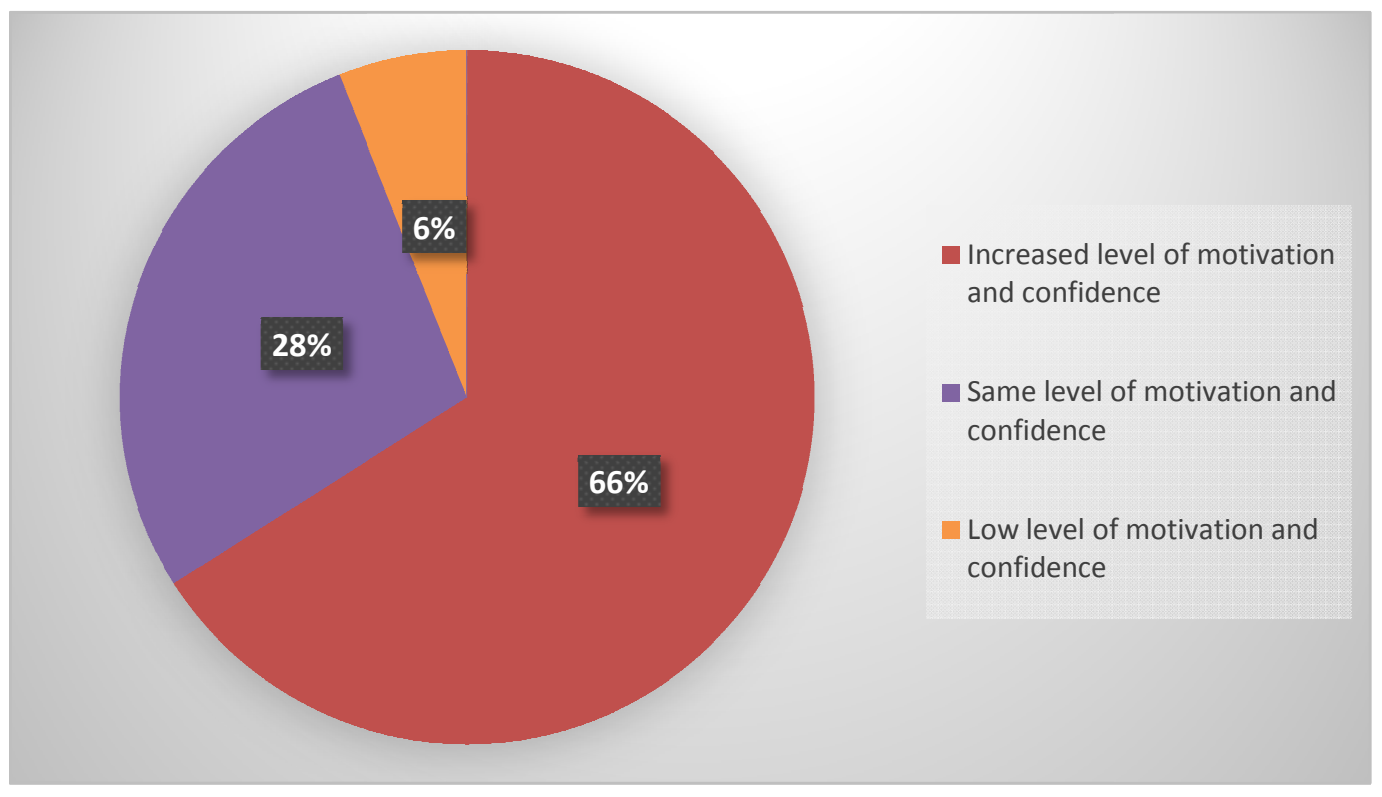

Chart 1. Distribution of students' answers to the descriptive questions as to their motivation and confidence after Kahoot-based training sessions

\section{CONCLUSIONS AND PROSPECTS FOR FURTHER RESEARCH}

Effective ESL teaching/learning has always been one of the most important interest areas for researchers and educators-practitioners. This paper contributes to the discussion on how the Kahoot game-based method of teaching ESL may affect the attitude of university students towards the language and their level of motivation and confidence to build their stronger communication skills.

The obtained data revealed that using Kahoot training sessions was successful in enhancing students' confidence and motivation in learning English. Only 6\% of students wrote in the descriptive questions that they had not built confidence and their level of interest in English learning remained low during the training sessions.

The fact that a vast majority of students revealed positive attitudes to using Kahoot in language learning suggests that this method could be of use when utilized systematically over the academic year. However, $11 \%$ considered using online games to be a waste of time and $22 \%$ of students thought that learning English should not have fun as a necessary requirement. It means, therefore, that an essential part of the teacher's role is to try various approaches and strategies to create a supportive learning environment in the classroom where learners feel interested, safe and secure to set and pursue their learning goals. In our further research, we will try to investigate other methods of keeping students motivated and engaged in ESL learning.

\section{REFERENCES (TRANSLATED AND TRANSLITERATED)}

[1] A. Talak-Kiryk, "Using Games In A Foreign Language Classroom", MA TESOL Collection, 484, 2010. (in English). 
[2] A. Yudintseva, "Game-Enhanced Second Language Vocabulary Acquisition Strategies: A Systematic Review". Open Journal of Social Sciences, 3: p. 101-109, 2015. (in English).

[3] B. Martinson, Sauman Chu, "Impact of Learning Style on Achievement When Using Course Content Delivered Via a Game-based Learning Object". [online].Available: https://experts.umn.edu/en/publications/impact-of-learning-style-on-achievement-when-using-coursecontent. (in English).

[4] E. Zarzycka-Piskorz, "Kahoot it or not? Can games be motivating in learning grammar?" [online]. Available: http://cejsh.icm.edu.pl/cejsh/element/bwmeta1.element.desklight-01599aa2-be08-430cb0cb-f57b6bdd4912. (in English).

[5] F. Rubio "Self-esteem and foreign language learning, introduction". [online]. Available: http://www.academicjournals.org/journal/ERR/article-full-text/2E1604B55425. (in English).

[6] H.J. Chen, W.C. Huang, "Examining the Potentials of Computer Games for English Learning".[online]. Available:

http://www.scirp.org/(S(351jmbntvnsjt1aadkposzje))/reference/ReferencesPapers.aspx?ReferenceID=1 604890. (in English).

[7] H.J.H. Chen, T.Y.C. Yang, "The Impact of Adventure Video Games on Foreign Language Learning and the Perceptions of Learners", Interactive Learning Environments, 21: p. 129-141, 2013. (in English).

[8] L.Yates, M. Chisari. "Building confidence in the classroom and beyond AMEP Longitudinal Study, Macquarie University". [online]. Available: https://www.neas.org.au/building-confidence-fact-sheet-1/ (in English).

[9] N. Iaremenko, "Enhancing English Language Learners Motivation through Online Games". [online]. Available: https://journal.iitta.gov.ua/index.php/itlt/article/view/1606. (in English).

[10] R.C. Gardner, "Motivation and Second Language Acquisition: The Socio-Educational Model". [online]. Available: http://www.tesl-ej.org/wordpress/issues/volume16/ej62/ej62r2/. (in English).

[11] R.M. Ryan, E.L. Deci, "Self-determination theory and the facilitation of intrinsic motivation, social development, and well-being," The American Psychologist, vol. 55, no. 1: p. 68-78, 2000. (in English).

[12] Y.A. Rankin et al, "User Centered Game Design: Evaluating Massive Multiplayer Online Role-Playing Games for Second Language Acquisition". [online]. Available: http://dx.doi.org/10.1145/1401843.1401851. (in English).

[13] Yu.O. Demianova, "Enhancing student collaboration through games in the ESL classroom". [online]. Available: http://journals.uran.ua/apppfo/article/view/114401

[14] Yu.O. Demianova, "Motivation in Foreign Language Learning". [online]. Available: http://journals.uran.ua/apppfo/article/view/83349. (in English).

[15] S. Tsymbal, "Overcoming Language Anxiety Among the English Language Learners: PsychoPedagogical Aspect".[online]. Available: http://scienceandeducation.pdpu.edu.ua/en/articles/2017-7doc/2017-7-st16-en. (in English).

\title{
ПІДВИЩЕННЯ РІВНЯ ВПЕВНЕНОСТІ ТА МОТИВАЦІЇ СТУДЕНТІВ У ВИВЧЕННІ АНГЛІЙСЬКОЇ МОВИ З ВИКОРИСТАННЯМ ІГРОВИХ ОНЛАЙН- ТРЕНIHГIB
}

\author{
Цимбал Світлана Володимирівна \\ кандидат психологічних наук, \\ доцент кафедри англійської мови для технічних та агробіологічних спеціальностей \\ Національний університет біоресурсів і природокористування України, м. Київ, Україна \\ svittsy@gmail.com
}

\begin{abstract}
Анотація. Ефективне викладання/навчання завжди було однією 3 найважливіших сфер наукового пошуку для дослідників, педагогів-практиків. Протягом останніх двадцяти років були розроблені методи навчання, спрямовані на підвищення мотивації та впевненості студентів 3 метою підвищення їхньої мовної компетенції. Студенти 3 вищим рівнем мотивації краще володіють англійською мовою, а ті, хто впевнені у своїх можливостях, мають більший успіх у навчанні. Студенти часто виявляють більш стійку мотивацію при можливості практичного й активного навчання. Вони можуть працювати над досягненням мети, вибираючи конкретні дії. Виконуючи ігрові дії, які симулюють реальність, студенти досягають більших результатів в оволодінні мовою. Сучасне суспільство постійно
\end{abstract}


змінюється і розвиває нові технології. Використання онлайн-ігор у процесі навчання англійської мови $є$ одним 3 таких методів, що якнайкраще урізноманітнюють процес навчання. У цій статті ми розглянули, як метод ігрового навчання Кахут може вплинути на ставлення студентів університету до англійської мови та рівень їхньої мотивації та впевненості. Отримані дані показали, що використання тренінгів за допомогою Кахут в основному було успішним у підвищенні рівня впевненості та мотивації студентів до вивчення англійської мови, і більшість студентів виявили позитивне ставлення до використання Кахут-ресурсу у вивченні мови. Проте $11 \%$ студентів вважають, що використання онлайн-ігор є марною тратою часу, а 22\% студентів вважають, що вивчення англійської мови не повинно перетворюватися на розвагу. Автор статті вважає, що метод онлайн-ігор може бути ефективним, якщо його систематично використовувати протягом навчального року. Проте викладачі університетів повинні застосовувати різні підходи та стратегії для створення сприятливого навчального середовища, де студенти почувалися б зацікавленими, впевненими в досягненні своїх навчальних цілей.

Ключові слова: впевненість; мотивація; викладання / навчання англійської; Кахут; тренінг; студенти університету.

\title{
ПОВЫШЕНИЕ УРОВНЯ УВЕРЕННОСТИ И МОТИВАЦИИ СТУДЕНТОВ В ИЗУЧЕНИИ АНГЛИЙСКОГО ЯЗЫКА С ИСПОЛЬЗОВАНИЕМ ИГРОВЫХ ОНЛАЙН-ТРЕНИНГОВ
}

\author{
Цымбал Светлана Владимировна \\ кандидат психологических наук, \\ доцент кафедры английского языка для технических и агробиологических специальностей \\ Национальный университет биоресурсов и природопользования Украины, г. Киев, Украина \\ svittsy@gmail.com
}

\begin{abstract}
Аннотация. Эффективное преподавание/обучение всегда было одной из важнейших сфер научного поиска для исследователей, педагогов-практиков. В течение последних двадцати лет были разработаны методы обучения, направленные на повышение мотивации и уверенности студентов с целью повышения их языковой компетенции. Студенты с более высоким уровнем мотивации лучше владеют английским языком, а те, кто уверены в своих возможностях, имеют больший успех в учебе. Студенты часто проявляют более стойкую мотивацию при возможности практического и активного обучения. Они могут работать над достижением цели, выбирая конкретные действия. Выполняя игровые действия, которые симулируют реальность, студенты достигают больших результатов в овладении языком. Современное общество постоянно меняется и развивает новые технологии. Использование онлайн-игр в процессе обучения английскому языку является одним из таких методов, которые привносят разнообразие в этот процесс. В этой статье мы рассмотрели, как метод игрового обучения Кахут может повлиять на отношение студентов университета к английскому языку и уровень их мотивации и уверенности. Полученные данные показали, что использование тренингов с помощью Кахут в основном было успешным в повышении уровня уверенности и мотивации студентов к изучению английского языка, и большинство студентов обнаружили положительное отношение к использованию Кахут-ресурса в изучении языка. Однако $11 \%$ студентов считают, что использование онлайн-игр является пустой тратой времени, а $22 \%$ студентов считают, что изучение английского языка не должно превращаться в развлечение. Автор статьи предполагает, что метод онлайн-игр может быть эффективным, если его систематически использовать в течение учебного года. Однако преподаватели университетов должны применять различные подходы и стратегии для создания благоприятной учебной среды, где студенты чувствовали бы себя заинтересованными, уверенными в достижении своих учебных целей.
\end{abstract}

Ключевые слова: уверенность; мотивация; преподавание/обучение английскому; Кахут; тренинг; студенты университета.

\section{$(c c)$ BY-NC-SA}

This work is licensed under Creative Commons Attribution-NonCommercial-ShareAlike 4.0 International License. 